\title{
An enigmatic Chironomidae (Diptera): First larval Description for Nandeva Wiedenbrug, Reiss and FitTKaU ANd EVIdence for PHYLOGENETIC POSITION IN TANYTARSINI
}

\author{
Peter S. Cranston \\ Evolution \& Ecology, Research School of Biology, Australian National University, \\ Canberra, A.C.T. 2601, Australia.E-mail:pscranston@gmail.com
}

\begin{abstract}
The previously unknown larva of the genus Nandeva Wiedenbrug, Reiss and Fittkau (Chironomidae: Chironominae) is suggested to be a candidate from tropical northern Australia belonging to the tribe Tanytarsini. The basis for the assumption is DNA analysis showing maximum values of Bayesian posterior probability and Bootstrap support for an exclusive sister relationship of the unreared larva with a male of Nandeva from South America. The monophyly of Nandeva has high support as a member of the subtribe Tanytarsina, although its precise relationships within this subtribe lack support. Larval morphology is described and illustrated, and conforms to the subtribe Tanytarsina in tribe Tanytarsini. The historical tempo is discussed in relation to fossils and dating of pertinent nodes and the term 'pseudo-gondwanan' is used to described an extant restricted austral range, but with fossils showing a wider past distribution in the north.
\end{abstract}

\section{Introduction}

Since the 'Holarctic Chironomidae' project (Wiederholm 1983, 1986, 1989), it has been desirable to incorporate morphology of immature stages in descriptive studies, faunal guides and classifications. Continuing unknown immature stages often are associated with atypical and under-sampled life histories such as terrestrial habitats or immersed wood (e.g. Cranston 2003, 2006) and/or from infrequently surveyed and remote places, such as New Zealand's subantarctic islands (e.g. Sublette and Wirth 1980). Amongst such genera with the larva unknown yet clearly aquatic is Nandeva Wiedenbrug, Reiss and Fittkau (1988) that is documented from diverse lotic pupal exuviae but until now with no associated larva.

Nandeva, based on the genotype Nandeva gaucha Wiedenbrug, Reiss and Fittkau, was described from the male imago and pupa from Rio Grande do Sul (southern Brazil), plus two species based solely on distinctive pupal exuviae from the Amazon basin (Brazil) and southern Chile, respectively
(Wiedenbrug et al. 1998). Further undescribed species suggest an extensive distribution in southern America, with an adult known from as far north as Panama.

Near simultaneously, this 'neotropical' genus was found in tropical northern Australian streams, with the sole species described as Nandeva fittkaui by Cranston (1999). Although all adults were pharate, associated pupae had the diagnostically posterior hook rows on tergites II-V, and lacked a thoracic horn, frontal setae, pedes spurii A and B, spur / comb on posterior segment VIII, and anal lobe fringe. Pupal exuviae were intercepted in drift from 6 streams in north-eastern Queensland between latitudes $16^{\circ}$ to $18^{\circ} \mathrm{S}$. Despite intensive conventional searching using kick and drift nets and breaking immersed wood, no candidate for the larval Nandeva was found.

Neotropical Nandeva diversity increased subsequently with two species described from São Paulo State, Brazil, together with a new pupal / adult association by Sæther and Roque (2004) who also keyed males of the then 5 described species. Additional species diversity was revealed by Andersen et al. (2011) in describing adults of a second species from Chile, another from Rio de Janeiro state in Brazil, with range extending to Mexico and Venezuela. Epler (2017) added Costa Rica to the meso-American distribution of the widely distributed species Nandeva latiloba Sæther and Roque. However, despite reports from aquatic ecological and biomonitoring researchers, no larval association was found (see e.g. Sæther and Roque 2004).

Because the larva remained unknown, its morphology could not be incorporated into phylogenetic studies. This was problematic as the adult male and pupa are morphologically very divergent (highly apomorphic) compared to prospective relatives. Regarding phylogeny, originally Wiedenbrug et al. (1988) stated only that the adult male belonged to the tribe Chironomini and, although keying to $\mathrm{Pa}$ gastiella, Nandeva differed substantially in details of phylogenetic significance. An early phylogenet- 
ic estimate was based on morphology in a matrix of 118 characters from all life-history stages for 60 genera of Chironominae, with larval features for Nandeva treated as 'missing data' (Cranston 1999). Analysed under strict parsimony, Nandeva fell within the tribe Chironomini, associated with Gondwanan-distributed genera Nilodosis Kieffer, Imparipecten Freeman, Fissimentum Cranston and Nolte and 'K1' (subsequently Xylochironomus Cranston). Some trivially less-parsimonious trees placed Nandeva as sister to Tanytarsini, or even embedded within the tribe. This latter placement found support from Sæther and Roque (2004), who reinterpreted wing vein RM as a continuation of direction of $\mathrm{R}_{4+5}$, diagnostic of tribe Tanytarsini. With this character state score emended in a revised matrix, analysed under a range of weighting schemes, Sæther and Roque (2004) proposed several positions for Nandeva, including as sister to, or within Tanytarsini, but with various different internal relationships. The position of Nandeva was argued as near or within tribe Tanytarsini based on male characters from the only known fossil species, N. pudens, from Fushun amber (early Eocene, NE China) by Giłka et al. (2016). Some morphology seemed driven by shared reductions likely to have been convergent, as suggested also by Cranston (1999). No proposed relationships had significant statistical support.

Detection of an Australian larva collected for molecular phylogenetic studies and linked by DNA sequences with an adult of Nandeva from Brazil, now allows association, and description of the larva. This provides better understanding of the phylogenetic relationships and the tempo of diversification.

\section{Material and methods}

Diverse and specifically targeted taxa of phylogenetic significance were sought for molecular phylogenetic studies across the Chironomidae (Cranston et al. 2011). Immature stages were obtained for ease of collection and relevance in aquatic biomonitoring programs. From a tropical submontane stream, larvae were recovered from semi-immersed leaf litter packs by coarse-sieving $(1 \mathrm{~cm}$ mesh) to remove larger material, and then using a $125 \mu$ mesh sieve to retain larvae. Samples were inspected live in the field under dissector microscope and larvae 'of interest' were placed individually in rearing vials. The larva subsequently recognised as possibly belonging to Nandeva, died prior to metamorphosis and 100\% isopropanol was added to the vial.

The Brazilian adult was collected into ethanol in a light trap located at Fazzara Creek, the type-locality for both Nandeva latiloba Sæther and Roque and N. strixinorum Sæther and Roque (2004).

Treatment of material for molecular study and protocols to obtain and align sequences and phylogenetic analyses were as reported in Cranston et al. (2011) and Krosch and Cranston (2012). Subsequent analyses with increased taxon sampling from tribe Tanytarsini follow Krosch et al. (2019). For the larva of Nandeva, DNA sequences (GenBank accessions in parentheses) were obtained for a mitochondrial protein-coding gene (COI, HQ440940), a ribosomal gene (18S, HQ440625), and two sections of the nuclear protein-coding gene (CAD, HQ440478, HQ440312). For the adult, only CO1 was obtained (HQ440941).

Specimens are vouchered (MV) as microscope slides in the Australian National Insect Collection, CSIRO, Canberra, Australia (ANIC).

\section{Results}

\section{Taxonomy}

Nandeva Wiedenbrug, Reiss and Fittkau 1998

Type-species: Nandeva gaucha Wiedenbrug, Reiss and Fittkau 1998, by original designation.

Larval material examined: 1L, AUSTRALIA, QUEENSLAND, Mt. Lewis, Mary Ck, 16³5.2'S $145^{\circ} 17.5^{\prime} \mathrm{E}$, 4.ix.2005, P.S. Cranston, MV FNQ9-3 (ANIC).

Adult $\widehat{\jmath}$, BRASIL, São Paulo, São Carlos, Córrego do Fazzari, 21 ${ }^{\circ} 58^{\prime}$ 'S 47 $53^{\prime} \mathrm{W}, 10 . v i i i .2007$, F.O. Roque, MV BRZNAND (ANIC).

\section{Description (Fig. 1).}

Small, colour in life unknown. Body length 3 mm., head length $250 \mu \mathrm{m}$, postmentum $90 \mu \mathrm{m}$. Dorsal head comprising frontoclypeal apotome with straight anterior margin, separate labrum and labral sclerites 3-5 distinct. Antenna (Fig. 1a) with pedestal undeveloped, 5-segmented, with swollen basal segment, segments decreasing successively in length from $2^{\text {nd }}$ to $5^{\text {th; }}$ length (in $\left.\mu \mathrm{m}\right) 58,20$, 13, 11, 6; Antennal ratio 1.1. Lauterborn organs prominent, equal to length of $3^{\text {rd }}$ antennal segment, both apical / subapical on $2^{\text {nd }}$ segment, one slightly retracted compared to the other. Style long. Ring organ near middle of segment 1, seta present. Blade extends well beyond flagellum, accessory blade very short. Labrum (Fig. 1b): SI plumose with fused bases; SII plumose, arising from small pedestals, SIII short, slender; SIV short, normally developed. Seta premandibularis simple, stout. Labral lamellae pectinate with c. 25 teeth. Pecten 


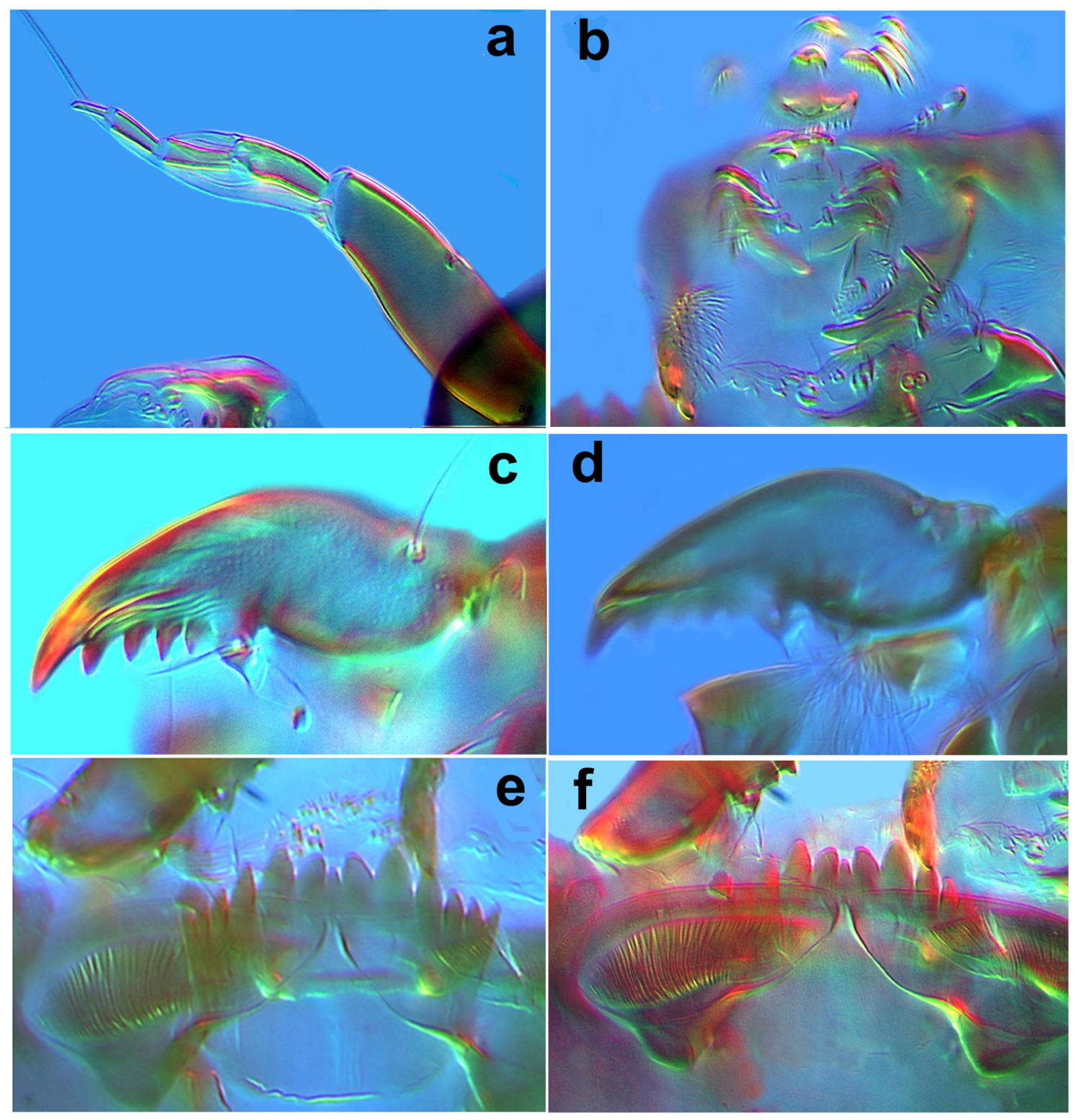

Figure 1. Nandeva fittkaui Cranston, putative larva. a. Antenna, b. Labrum, c. Mandible ventral, c. Mandible ventral, e. Mentum, with teeth enhanced, f. Mentum with ventromental plates enhanced.

epipharyngis tripartite, each tooth pectinate with 5-6 teeth distally. Premandible $40 \mu \mathrm{m}$ long, with 3 teeth, with beard. Mandible (Figs 1c, d) $70 \mu \mathrm{m}$ long, with stout dorsal tooth; apical tooth $2 x$ length of one of 3-4 inner teeth; all teeth pale brown. Pecten mandibularis absent. Seta subdentalis inserted dorsally, narrow, reaching middle inner tooth. Seta interna multi-branched, inserted on dorsal surface. Mentum (Figs. 1e, f) $62 \mu \mathrm{m}$ wide, with all teeth pale brown. Median (ventro-) mentum with three teeth, the central one recessed, smaller; with 5 pairs of lateral teeth, declining in size; pointed outermost tooth lies somewhat displaced laterally relative to the inner. Ventromental plates (Fig. 1f) $60 \mu \mathrm{m}$ wide, distinctively subovoid, in contact medially, with smooth anterior margin, striae concentrated in medio-lateral area and absent from median sector. Setae submenti apparently simple. Body lacks lateral or ventral tubules. Segment 11 dorsomedially without appendages or hump. Procercus simple, unpigmented, arising directly from membrane, with few short anal setae.

\section{Taxonomic and Ecological Comments}

Although there are no formal diagnoses for the tribe Tanytarsini, these can be derived from Sæther (1977) including also for subtribes Tanytarsina and Zavreliina, and from keys such as Epler et al. (2013) for Holarctic larvae. The larva proposed here as belonging to Nandeva conforms to 
tribe Tanytarsini in the subfamily Chironominae, largely based on features of the labro-epipharynx. Notably the labral SI and SII setae are plumose, the bases of S1 setae are fused and SII are on pedestals. The antenna is 5 segmented with antennal seta, with sessile, opposite Lauterborn organs not on pedestals. The ventromental plates are in near median contact, diagnostic of subtribe Tanytarsina. Within this subtribe, the recessed median mental tooth and the mandible with dorsal tooth and seta subdentalis appearing to be inserted dorsally (which is seen otherwise only in tribe 'Pseudochironomini') appear to be diagnostic.

The Australian larva is associated with South American Nandeva at $89 \%$ similarity of sequence from molecular evidence (Cranston et al. 2011, Krosch et al. 2019). The larval collection site is a 2nd order creek at $1000 \mathrm{~m}$. above sea level in tropical north Queensland. All other Australian records of Nandeva are from the characteristic pupal exuviae from streams in Far North Queensland including from Mary Creek that is the larval locality (Cranston 1999). No such larvae have been found in any other stream from which this pupal type derives, despite intensive sampling for over two decades. Circulating photographs of the Australian larvae amongst South American colleagues has not elicited recognition and this larval type remains unknown there.

\section{Phylogeny}

Seeking data for an extensively sampled molecular phylogenetic reconstruction, Cranston et al. (2011) obtained representatives across all available major branches of the Chironomidae. Survey strategy often targeted larvae with distinctive morphologies (see Cranston et al. 2011, including Supplementary Material) and most were unreared. Amongst these was a solitary larva from immersed leaf litter from Mary Creek at $1000 \mathrm{~m}$. elevation above sea level on Mount Lewis on the Atherton Tableland of tropical northern Queensland, which is the type-locality of Nandeva fittkaui. Amongst material collected by colleagues was an adult Nandeva from the Fazzari Stream in Sao Carlos, Brazil was made available to us by Fabio Roque. As shown in Cranston et al. 2011: fig. 2), the sequence data from the isolated Australian larva and the Brazilian adult midge form a tight cluster, allowing the inference that they were each other's closest relatives, likely to be congeners. Phylogenetic analyses (loc. cit.) implied that Nandeva was sister to Riethia, represented by four specimens, belonging to only 2 species (Cranston 2019). Although the subtending node lacked support, at the next level the sister group was proposed as tribe Tanytarsini (Cranston et al. 2010: node C5, with 100\% support). Although polythetic, morphological taxonomic concepts of tribe and subtribes thus find strong support from molecular analyses (Cranston et al. 2011; Krosch et al. 2019). Further elaborations of expanded morphological matrices and analyses under various forms of parsimony have shown Nandeva as belonging within the well-circumscribed Tanytarsini (Andersen et al. 2011) - in an arrangement found in some slightly suboptimal molecular results. Now a recent analysis combines new and existing molecular data, from more intensive sampling within Tanytarsini and greatly expanded by addition of Pseudochironomus and many more species of Riethia (Krosch et al. 2019). The analysis (Fig. 2, modified from Krosch et al. 2019, fig. 1) now clearly locates Nandeva within Tanytarsini, with 100\% Bayesian Posterior Probability (PP) and .93 Bootstrap support (BS)), and within subtribe Tanytarsina (99\% PP, .85 BS). Nandeva attaches as sister to the clade comprising (Sublettea (Paratanytarsus + Micropsectra), but with weak support of only $90 \%$ (PP). Contrary to previous predictions, addition of larval characters to the morphological matrix and re-analysed using parsimony, does not strengthen support for any of the previously inconsistent proposed relationships (Cranston pers. obs.).

\section{Tempo of diversification}

The major difference between analyses of the tempo of diversification in Cranston et al. $(2010,2011)$ and Krosch et al. (2019) is the use of new and different fossils to calibrate the BEAST analyses. Well-dated, newly studied, amber fossils include those assigned to Tanytarsini, including Tanytarsus (Giłka 2011; Giłka et. al. 2013; Zakrzewska and Giłka 2014, 2015b; Zakrzewska et al. 2016; Zakrzewska et al. 2018) and to Nandeva (Giłka et al. 2016). Temporal analysis (Fig. 2, red \# below line is median age in Ma (million years before present) shows two highly-supported splits, between subtribes Tanytarsina and Zavreliina of $74 \mathrm{Ma}$ (with range $61.1-90.8 \mathrm{Ma}$ ) and the later split between Cladotanytarsus + Tanytarsus and remaining members of the subtribe at $56 \mathrm{Ma}$ (51.3-63.8 Ma). Although the node connecting Nandeva within Tanytarsini is unsupported, a date (and range around this node) of $42 \mathrm{Ma}(33.2-49.6$ $\mathrm{Ma}$ ) can be postulated. This is expected, as we had applied the Eocene calibration fossil Nandeva pudens (Giłka et al. 2016) to the stem at $49.5 \mathrm{Ma}$, a youngest age attributed to Fushun amber, with the value of $42 \mathrm{Ma}$ applying to the crown age. 


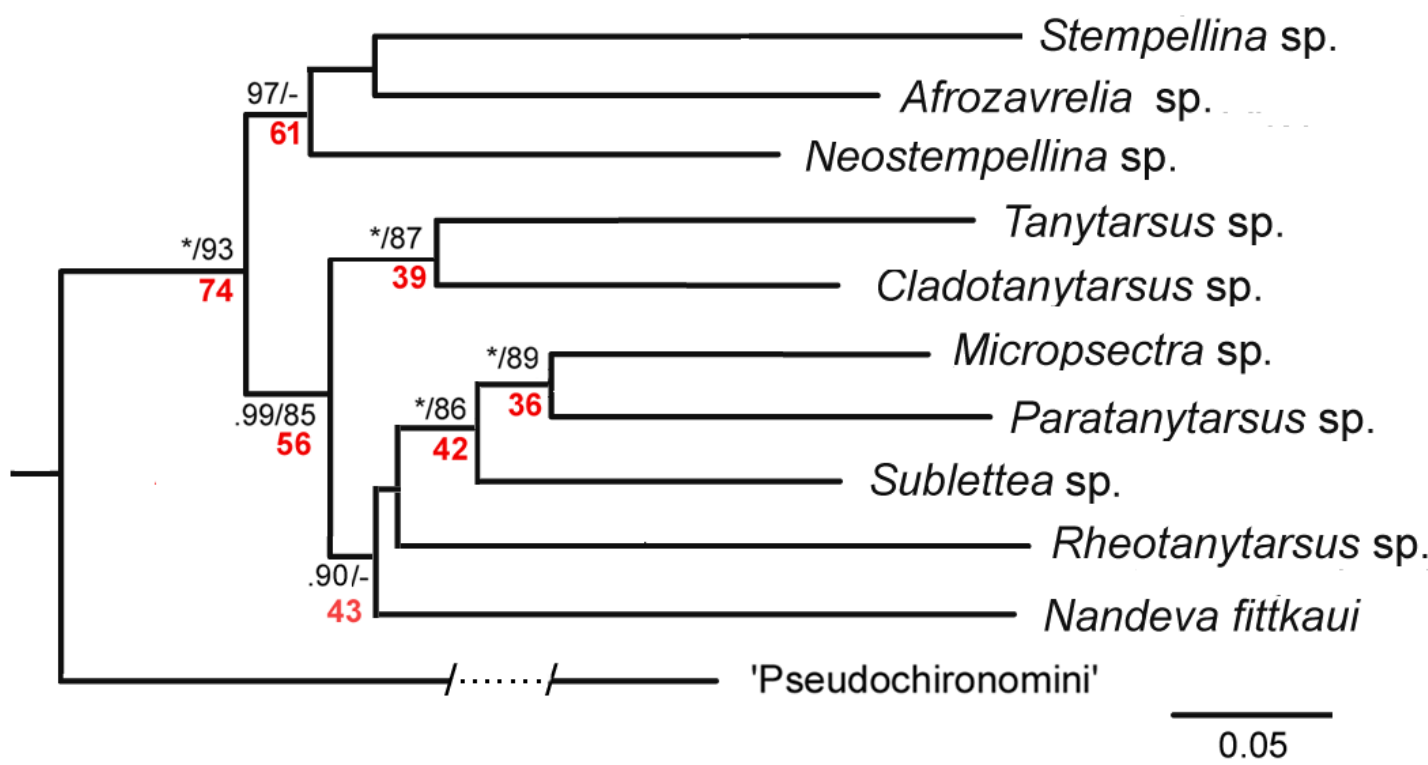

Figure 2. Bayesian dated tree for Tanytarsini, 'Pseudochironomini', terminals reduced from Krosch et al. (submitted 2019). Above node, black \# Support statistics. * - maximum Bayesian posterior probability (1.00), - = maximum bootstrap (100), .xx/yy Bayesian posterior probability / bootstrap value. Below node, red \# is mean date in Ma (million years before present). ........ indicates attenuated distance.

Thus stem Tanytarsini originated in the late Cretaceous and commenced radiation as the extant tribe (crown group) in the end Cretaceous with the progenitors of the two subtribes. Subsequent radiation into extant genera of Tanytarsini took place through the Palaeogene, although fossil evidence is lacking, with most median dates of splits in the Palaeocene and Eocene. Sampled extant genera including Nandeva are postulated as existing crown groups by the late Eocene, which is in keeping with the fossil evidence.

\section{Discussion}

Studies of the Chironomidae have elucidated southern hemisphere ('austral') biogeography, commencing with Brundin's seminal works (1963, 1965, 1966). Although Brundin used 'manual' Hennigian phylogenetics and somewhat subjective temporal reconstructions, studies substantially confirm Brundin's vicariance-based reconstructions, notably Cranston et al. (2011) across the whole family and for subfamilies Podonominae (Cranston et al. 2010), Orthocladiinae (Krosch et al. 2011) and Tanypodinae (Krosch et al. 2017). Well-dated reconstructions recover a tempo of midge evolution that tracks Gondwanan fragmentation, even involving southern Africa that allows inference of a vicariance date of $>100 \mathrm{Ma}$ (Cranston et al. 2011). Younger patterns include New Zealand (e.g. Krosch and Cranston 2013), but most vicariant taxa are separated from South America - Australian connection via Antarctica (van der Ende et al. 2017).

Calculations of the tempo of diversification relative to earth history have been greatly enhanced since Brundin's time. A cadre of insect palaeontologists are describing well-preserved and carefully dated fossils, particularly from amber-preserved specimens dating back up to $100 \mathrm{Ma}$. With respect to this study, Giłka, Zakrzewska and colleagues continue to provide valuable data on Eocene amber inclusions. In addition to dated and taxonomically informative 'calibration points', are improvements in phylogenetic and temporal diversification analyses, based on molecular data using both Maximum Likelihood and Bayesian methods of analysis.

In a dated phylogeny (Cranston et al. 2011) both sampled Nandeva were monophyletic, with the stem node (although as sister to Riethia) dated at $47 \mathrm{Ma}(30-67 \mathrm{Ma})$ (unpublished supporting information). Note that this analysis did not use Nandeva in calibration. The South American Nandeva had to be excluded from the analysis of the Krosch et al. (submitted 2019) analysis of the tempo of diversification because its molecular representation was only by COI. However, with or without the S. American Nandeva, and independent of close calibration points in Tanytarsini, 
including for Nandeva, the median date for stem Nandeva converges on early-mid Eocene, which is the date of the fossil $N$. pudens.

The locations and diversity of extant Nandeva imply concordance with timing for south American vicariance from Australia via Antarctica which was temperate and connected until the opening of the Drake Passage at c. $30 \mathrm{Ma}$, and the final break from Australia via the Antarctica landbridge, along the South Tasman Rise at c. $45 \mathrm{Ma}$ (van der Ende et al. 2017). However, that this represents a "southern disjunct" or "amphinotic" (Cranston 2005) distribution may be tempered by Nandeva occurring in more tropical streams as well as the usual cool temperate distributions of such clades. Although Amorim and Santos (2017) demonstrate that Brazil's Southern Atlantic Forest contains amphinotic elements, and Nandeva are found there, it is clear that they occur also in truly tropical streams.

Of greater significance is the undeniable presence of Nandeva in early Eocene Fushun (Palaearctic China) and the fossil genus Eonandeva (possibly stem Nandeva) from slightly younger Baltic amber (Zakrzewska and Giłka 2015b). Such ancient presence of stem groups of 'gondwanan' crown taxa, are discussed by Giłka et al. (2016) for Chironomidae. Other examples include termites of the family Mastotermitidae, the sister group to the remaining extant termites, is known from the Miocene to Eocene of Europe, Mexico, and the Dominican Republic and perhaps Cretaceous fossils in the Palearctic is reduced now to Mastotermes darwiniensis, a pest in northern Australia. The bulldog ants (subfamily Myrmeciinae), now restricted to Australia, indubitably include fossil taxa from Argentina and the Baltic. The biting midge Austroconops (Ceratopogonidae, Leptoconopinae) abundant in Lebanese and other Cretaceous ambers, is represented now by two species in Western Australia. Differential extinction in the northern hemisphere with survival in the south, seems to be frequent, giving rise to a 'pseudo-gondwanan' distribution (Cranston and Gullan 2005). Nandeva appears to qualify for this term.

One more issue remains to be addressed here, that the Australian N. fittkaui differs from the studied neotropical species in enough features that could encourage allocation to a different genus to the neotropical species (Andersen et al. 2011). Some structures are difficult to confirm due to Australian adult material all being in a pharate state. As documented by Andersen et al. (2011) differences include the absence of lateral antepronotals, the bare squama, spatulate anal point and superior volsella with more basal setae and strong microtrichia. In the female genitalia the ventrolateral lobe is strongly microtrichiose and in the same plane as the dorsomesal lobe, the spermathecal ducts are nearly straight, a floor seems absent, and the setae of tergite IX are divided into two groups. The pupal tergites VI-VII lack the antero-median patches of stronger spinules seen in the Neotropics. We still lack non-teneral adults for confirmation of the adult differences, yet can be sure that even if a new rank is 'needed' for $N$. fittkaui, it surely will be sister to the neotropical clade, and inferences here concerning evolution and biogeography will be unaffected.

\section{Acknowledgements}

I am very grateful to my colleague Fabio de Oliveira Roque, now of Faculdade de Ciências Biológicas e Ambientais, Universidade Federal da Grande Dourados, Brazil, for collecting molecular quality material for me from the type localities of two Nandeva species. I thank Susana Strixhino and her colleagues for seeking the larval type described here, albeit without success. In Australia, for nearly 15 years I have valued the company and field assistance including in Australia's Wet Tropics of Matt Krosch, now of Queensland Police Service Forensic Services Group. Matt undertook several phylogenetic analyses that included Nandeva; other molecular collaborators include Nate Hardy (now Auburn University, AL, USA) and Geoffrey Morse (now University of San Diego, CA, USA). I valued discussion with Viktor Baranov (Department of Biology, Ludwig-Maximilans-University, Munich Germany) and Wojciech Giłka (University of Gdańsk, Poland) concerning the fossil evidence cited here. Permits for collecting in Queensland were aided by The Entomological Society Queensland agreements organised by Chris Lambkin, for which deepest thanks.

\section{References}

Amorim, D.S. and Santos, C.M.D. 2017. Flies, endemicity, and the Atlantic Forest: a biogeographical study using topographic units of analysis. - Australian Systematic Botany 136: 439-469. DOI: https://doi.org/10.1071/ $\underline{\mathrm{SB} 16057}$

Andersen, T, Sæther, O.A. and Contreras-Ramos, A. 2011. New species and records of Nandeva Wiedenbrug, Reiss et Fittkau (Chironomidae: Chironominae). - Zootaxa 3136: 45-60.

Brundin, L. 1963. Limnic Diptera in their bearings on the problem of transantarctic faunal connections. In: Gressit, J.L. (Ed.), Pacific Basin Bio- 
geography. Bishop Museum Press, Honolulu.

Brundin, L. 1965. On the real nature of transantarctic relationships. - Evolution 19: 496-505.

Brundin, L. 1966. Transantarctic relationships and their significance as evidenced by chironomid midges: with a monograph of the sub-families Podonominae and Aphroteniinae and the Austral Heptagyiae. - Kunglica Svenska Vetenskapsakademiens Handlingar 11: 1-472 + plates.

Cranston, P.S. 1999. Two unusual Chironomini (Diptera: Chironomidae) from Australian rainforest streams: one new genus and a neotropical genus new for the region. - Australian Journal of Entomology 38: 291-299.

Cranston, P.S. 2003. The oriental genus Shangomyia Sæther \& Wang (Chironomidae: Diptera): immature stages, biology, putative relationships and the evolution of wood mining in chironomid larvae. - The Raffles Museum Bulletin of Zoology 51: 179-186.

Cranston P.S. 2005. Biogeographic patterns in the evolution of Diptera. In Yeates D.K. and Wiegmann B.M. (eds) 'The Evolutionary Biology of Flies. Columbia University Press: New York, NY, USA pp. 274-311.

Cranston, P.S. 2006. A new genus and species of Chironominae (Diptera: Chironomidae) with wood-mining larvae. - Australian Journal of Entomology 45: 227-234.

Cranston, P.S. 2019. Riethia (Kieffer 1917) (Diptera: Chironomidae) revised for the Austro-Pacific Region. - Zootaxa 4646: 461-500. DOI: http://dx.doi.org/10.11646/zootaxa.4646.3.3

Cranston, P.S. and Gullan, P.J. 2005. Time flies. Evolution 59(11): 2492-2494.

Cranston, P.S., Hardy, N.B., Morse, G.E., Puslednik, L. and McCluen, S.R. 2010. When molecules and morphology concur: the 'Gondwanan' midges (Diptera: Chironomidae). - Systematic Entomology 35: 1-13. DOI: https:// doi.org/10.1111/j.1365-3113.2010.00531.X

Cranston, P.S., Hardy, N.B. and Morse, G.E. 2011 [2012]. A dated molecular phylogeny for the Chironomidae (Diptera). - Systematic Entomology 37: 172-188. DOI: https://doi. org/10.1111/j.1365-3113.2011.00603.x

Dominiak, P., Szadziewski, R. and Nel, A. (2018) A new species of the haematophagous genus Austroconops Wirth \& Lee (Diptera: Ceratopogonidae: Leptoconopinae) from middle Cretaceous amber of Charente-Maritime, France.
- Cretaceous Research 92: 231-239. DOI: https://doi.org/10.1016/j.cretres.2018.08.005

Epler, J.H. 2017. An annotated preliminary list of the Chironomidae (Diptera) of Zurquí, Costa Rica. - CHIRONOMUS Journal of Chironomidae Research 30: 4-18. DOI: https://doi. org/10.5324/cjcr.v0i30.2240

Epler, J.H., Ekrem, T. and Cranston, P.S. 2013. The larvae of Chironominae (Diptera: Chironomidae) of the Holarctic region - keys and diagnoses. In Andersen, T., Cranston, P.S. and Epler, J.H. (Sci. Eds.), The larvae of Chironomidae (Diptera) of the Holarctic Region - Keys and diagnoses. Insect Systematics \& Evolution Supplement, 66: 387-556.

Giłka, W. 2011. A new fossil Tanytarsus from Eocene Baltic amber, with notes on systematics of the genus (Diptera: Chironomidae). - Zootaxa 3069: 63-68.

Giłka, W., Zakrzewska, M., Dominiak, P. and Urbanek, A. 2013. Non-biting midges of the tribe Tanytarsini in Eocene amber from the Rovno region (Ukraine): a pioneer systematic study with notes on the phylogeny (Diptera: Chironomidae). - Zootaxa 3736: 569-586. DOI: http://dx.doi.org/10.11646/zootaxa.3736.5.8

Giłka, W., Zakrzewska, M., Baranov, V., Wang, B. and Stebner, F. 2016. The first fossil record of Nandeva Wiedenbrug, Reiss \& Fittkau (Diptera: Chironomidae) in early Eocene Fushun amber from China. - Alcheringa: An Australasian Journal of Palaeontology 40: 390-397. DOI: https://doi.org/10.1080/03115518.2016.1 145529

Krosch, M.N. and Cranston, P.S. 2012. Non-destructive DNA extraction, including of fragile pupal exuviae, extends analysable collections and enhances vouchering. - CHIRONOMUS Journal of Chironomidae Research 25: 22-27. DOI: https://doi.org/10.5324/cjer.v0i25.1532

Krosch, M.N. and Cranston, P.S. 2013. Not drowning, (hand)waving? Molecular phylogenetics, biogeography and evolutionary tempo of the 'gondwanan' midge Stictocladius Edwards (Diptera: Chironomidae). - Molecular Phylogenetics and Evolution 68: 595-603. DOI: https://doi.org/10.1016/j.ympev.2013.04.006

Krosch, M.N., Baker, A.M., Mather, P.B. and Cranston, P.S. 2011. Systematics and biogeography of the Gondwanan Orthocladiinae (Diptera: Chironomidae). - Molecular Phylogenetics and Evolution 59: 458-468. DOI: https:// doi.org/10.1016/j.ympev.2011.03.003 
Krosch, M.N., Cranston, P.S., Bryant, L.M., Strutt, F. and McCluen S.R. 2017. Towards a dated molecular phylogeny of the Tanypodinae (Chironomidae, Diptera). - Invertebrate Systematics 31: 302-316. DOI: https://doi.org/10.1071/ IS16046

Krosch, M.N., Herold, N., Thornhill, A.H. and Cranston, P.S. 2019. How 'Gondwanan' is Riethia (Diptera: Chironomidae)? Molecular phylogenetics elucidates the tempo of diversification in the Austro-Pacific. - Invertebrate Systematics in press.

Sæther, O.A. 1977. Female genitalia in Chironomidae and other Nematocera: morphology, phylogenies, keys. - Bulletin of the Fisheries Research Board of Canada, 197: 1-211.

Sæther, O.A. and Roque, F.O. 2004. New Neotropical species of Nandeva (Diptera: Chironomidae), with a phylogeny of the Tanytarsini. Tijdschrift voor Entomologie 147: 63-80. DOI: https://doi.org/10.1163/22119434-900000141

Sublette, J.E. and Wirth, W.W. 1980. The Chironomidae and Ceratopogonidae (Diptera) of New Zealand's subantarctic islands. - New Zealand Journal of Zoology 7: 299-378. DOI: https:// doi.org/10.1080/03014223

van der Ende, C., White L.T. and van Welzen, P. C. 2017. The existence and break-up of the Antarctic land bridge as indicated by both amphi-Pacific distributions and tectonics. - Gondwana Research 44: 219-227. DOI: https://doi. org/10.1016/j.gr.2016.12.006

Wiedenbrug, S., Reiss, F. and Fittkau, E.J. 1998. Nandeva, gen. nov., a new genus of Chironomini (Insecta, Diptera, Chironomidae). Spixiana 21: $59-68$.

Wiederholm, T. (Ed.) 1983. Chironomidae of the Holarctic region. Keys and diagnoses. Part 1.
Larvae. Entomologica scandinavica Supplement 19, $457 \mathrm{p}$.

Wiederholm, T. (Ed.) 1986. Chironomidae of the Holarctic region. Keys and diagnoses. Part 2. Pupae. Entomologica scandinavica Supplement 28, 482 p.

Wiederholm, T. (Ed.) 1989. Chironomidae of the Holarctic region. Keys and diagnoses. Part 3. Adult males. Entomologica scandinavica Supplement 34, 532p.

Zakrzewska, M. and Giłka, W. 2014. The oldest known chironomids of the tribe Tanytarsini (Diptera: Chironomidae) indicate plesiomorphic character states. - Geobios 47: 335-343. DOI: https://doi.org/10.1016/j.geobios.2014.07.004

Zakrzewska M. and Giłka W. 2015a. The Tanytarsini (Diptera: Chironomidae) in the collection of the Museum of Amber Inclusions, University of Gdańsk. - Zootaxa 3946: 347-360. DOI: https://doi.org/10.11646/zootaxa.3946.3.3

Zakrzewska, M. and Giłka, W. 2015b. Eonandeva gen. nov., a new distinctive genus from Eocene Baltic amber (Diptera: Chironomidae). - Zootaxa 4044: 577-584. DOI: http://dx.doi. org/10.11646/zootaxa.4044.4.7

Zakrzewska, M., Krzemiński, W and Giłka, W. 2016. Towards the diversity of non-biting midges of the tribe Tanytarsini from Eocene Baltic amber (Diptera: Chironomidae). - Palaeontologia Electronica 19.2.18A: 1-21.

Zakrzewska, M., Stebner, F., Puchalski, M., Singh, H., and Giłka, W. (2018). A peculiar leg structure in the first non-biting midge described from Cambay amber, India (Diptera: Chironomidae). - Earth and Environmental Science Transactions of the Royal Society of Edinburgh 107: 255-261. DOI: https://doi.org/10.1017/ $\underline{\mathrm{S} 1755691017000421}$

Article submitted 22. September 2019, accepted by Torbjørn Ekrem 31. October 2019, published 3. November 2019. 